УДК 351.862.21:027.52(497.11 Шабац) $\left.351.759 .6: 627.51^{\prime \prime} 2014^{\prime \prime}\right] \cdot 027.52(497.11$ Шабац) 616.98-036.21/.22:578.834"2020“]:027.52(497.11 Шабац)

\title{
Библиотеке и црвени аларм: искуство Библиотеке шабачке у поплави и пандемији Covid-19
}

\author{
Небојша Цвејић \\ Библиотека шабачка \\ nebojsacvejic@gmail.com
}

\begin{abstract}
Сажетак
Две кризне ситуације, поплава 2014. и пандемија Covid-19 2020. године, проузроковале су велике измене у раду Библиотеке шабачке. Директно ангажовани на терену, библиотекари су током тих кризних периода рад установе прилагодили датим околностима. У раду су анализиране сличности и разлике у пословању у току две наведене ванредне ситуације. У оба случаја, Библиотека је морала да измени свој уобичајени рад са корисницима, а библиотекари да се укључе у пружање помоћи локалној заједници. Разлика је у томе што је, приликом поплаве била угрожена имовина, а у време пандемије живот и здравље људи. Библиотека шабачка је у обе ситуације показала своју способност прилагођавања, тако да је успела да задржи своје кориснике и унапреди информациони и едукативни рад са њима.
\end{abstract}

Кључне речи: Библиотека шабачка, ванредно стање, поплава, пандемија Covid-19, библиотекари, библиотечки фондови, услуге, друштвене мреже, хуманитарни рад

Увод

У тексту је приказана организација рада Библиотеке шабачке у време две ванредне ситуације (2014. и 2020. године). Упоређен је рад библиотеке током поплаве у мају 2014. и током пандемије Covid-19 2020. године. Указано је на сличности и разлике у начину деловања у кризним ситуацијама. Рад је у оба случаја био обустављен те је обнављан након проласка опасности. Поплава, као природна катастрофа, директно је угрозила зграду и сам фонд који је у њој похрањен. Запослени су ангажовани да бране и заштите имовину (зграду која је културно добро заштићено законом, опрему и библиотечке фондове).

У другом случају, током пандемије Covid-19 2020. године, на првом месту су били здравље и безбедност људи. Поштујући прописане епидемиолошке мере, библиотекари су, осим свог свакодневног, али редукованог посла, пружали помоћ суграђанима на различите начине.

Анализа показује како су изгледале измене у свакодневном раду, како су утицале на број корисника и како су они прихватили нов начин рада. Притом су промотивне активности у потпуности престале, а ситуација је налагала да се пређе на нов, онлајн начин пословања.

\section{Библиотека шабачка у време поплава}

Непогоде, било које врсте, природне или вештачке, чине велику штету и уносе пометњу у свакодневни живот становништва. Суочавање са њима имала је и Библиотека шабачка два пута у току новог миленијума. Није ни први пут, а није ни катастрофално, како је то умело у прошлости да бива. Најдрастичнији пример је онај из августа 1914. године, када је објекат у 
коме је библиотека била смештена потпуно уништен. ${ }^{2}$

Прва од две пошасти о којима је овде реч, стигла је у мају 2014. године. Водена стихија која је угрозила део простора југоисточне Европе, озбиљно је запретила и становништву Мачванског округа. Кишни дани са великом количином падавина нису у први мах покренули активности у вези са превентивом и заштитом од евентуалне поплаве. Отежавајућу околност представља положај самог града у односу на реку: Сава је у свом току најшира управо код Шапца, а ток реке уз десну обалу је нешто бржи. Евентуално изливање би довело до тога да читав град буде поплављен. Шабац, за разлику од осталих урбаних насеља у Округу, једини се налази у равници. Мост преко реке Саве му је сигурна одступница ка северу. Први знаци надолазеће катастрофе очитавали су се у изливању притока Дрине и прекиду саобраћаја на правцу од Шапца ка југозападу и Љубовији. Бујични токови такође су направили велики проблем те се то итекако осетило у мањим местима која су у одређеној мери и оштећена (Љубовија, Коцељева и Крупањ). У самом граду Шапцу, дошло је до појаве воде на улицама и у двориштима, канализација се изливала и делови града су били непроходни за саобраћај. Ободни канали су се напунили водом до врха и угрожавали су насеља у својој близини.

Реакција грађана и захтеви да се организовано приступи одбрани од поплаве нису наишли на адекватан одзив код градске власти. Пораст нивоа Саве и обреновачка катастрофа покренули су коначно механизам те се почело са предузимањем одговарајућих мера. У граду је проглашено ванредно стање, па су, у складу са њим, и јавне (буџетске) установе обуставиле свој рад.

Библиотека шабачка, као институција коју финансира град Шабац, подлеже радној обавези и дужна је да обезбеди људство за извршавање задатака и послова које пред њу поставља оснивач. Библиотека је затворила своја врата корисницима и уведено је двадесетчетворочасовно дежурство. Старије и болесне колегинице и колеге изузете су од ове обавезе.

Мушки чланови колектива, уз поједине колегинице, добили су радну обавезу да на посао долазе ноћу, док су библиотекарке дежурале у току дана. Рад са корисницима није био могућ, прво због уведеног ванредног стања, али и због велике количине падавина које су се тих дана сручиле на град. Поједине градске улице биле су непроходне, вода је плавила дворишта те кретање кроз неке делове града није било изводљиво. Све активности Библиотеке које се односе на рад са корисницима и промотивне активности у том периоду су биле угашене, јер се водила брига о заштити људства, непокретне имовине и културних добара.

Зграда библиотеке обезбеђена је џаковима са песком који су распоређени око капија, свих врата и подрумских прозора. Фонд у приземљу подигнут је на ниво виши од једног метра, како би се избегло оштећење током евентуалног продора воде. Дежурни библиотекари добили су кишне кабанице и дубоке гумене чизме. Како је подрум зграде испод нивоа улице, вода је почела да продире у те просторије. Постојећа пумпа није била довољна да избаци толику количину воде те је она првобитно избацивана кофама, а потом су набављене додатне потапајуће пумпе, које су проблем и отклониле.

По престанку кишних дана, наступила је нова фаза одбране. Добар део Округа је био под водом и тешко се могло стићи до појединих тачака. У Шабац су стигле спасилачке екипе из Русије, Белорусије, Словеније и Аустрије са свом потребном опремом.

Током трајања кризе, у град су свакодневно стизали добровољци из целе Републике и у великој мери помогли су у одбрани (Ниш, Врање, Лесковац, Нови Пазар, Београд, Нови Сад, Зрењанин и др). Полиција и војска са механизацијом све време су биле присутне и активно се ангажовале у радовима. Свима њима који су себе уградили у бедеме који су штитили град и

\footnotetext{
1 Реч је о кафани Злашни јелен или популарније Јелен, која се налазила у делу града који се зове Баир, а налази се ближе реци Сави. До тада је библиотека била смештена у Крсмановића кући, репрезентативном здању у самом центру Шапца.

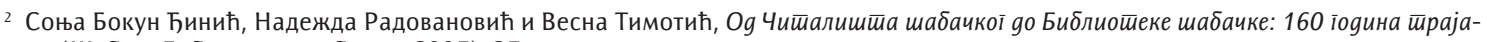
ња (Шабац: Библиотека шабачка, 2007), 27.
} 
околину, Шабац и сви његови грађани дугују велику захвалност. Значајна је и подршка струковних колега: библиотекари из целе Србије непрекидно су се јављали нудећи помоћ и смештај у свом дому.

Нова фаза након престанка падавина био је одлазак на насип у околини Шапца. Најкритичније је било узводно од града, на месту званом Чеврнтија, ${ }^{3}$ које се налази на путу ка Сремској Митровици. Као и код самог града, река ту има кривину и десна обала је у опасности више него лева.

Мушки део колектива Библиотеке, заједно са другим радницима из јавних предузећа, упућен је на Чеврнтију. Тамо је постојећа обалоутврда ојачавана и подизана уз помоћ џакова са песком. Полазак је организован испред хале, где су смештене спасилачке екипе. Колегинице су, у време радова на Чеврнтији, биле ангажоване у Црвеном крсту. Тамо су правиле сендвиче, који су дистрибуирани на све коте одбране града.

Нови поплавни талас који се приближавао Савом из правца Хрватске био је изнад линије одбрана од поплаве. Пробијањем насипа код Жупање (Хрватска), река се излила, па је опасност прошла. Смиривањем водостаја претња је отклоњена те су библиотекари, као и сви људи који су ангажовани, враћени својим текућим обавезама.

И наредне 2015. године, када се услед нових обилних падавина, подигао ниво Саве, библиотекари су наново распоређени на радне задатке, с тим да овај пут пуне вреће са песком. За разлику од претходне сезоне, ситуација се брзо и повољно разрешила те је и веће ангажовање изостало.

\section{Библиотека шабачка у времену пандемије Covid-19}

Наредна криза која је изискивала нов, активан труд библиотекара, долази на почетку 2020. године. Ванредна ситуација проглашена средином марта исте године, ${ }^{4}$ приморала је запослене у Библиотеци да пређу на режим рада прописан препорукама и наредбама о пословању у току ванредног стања проглашеног услед пандемије Covid-19. ${ }^{5}$ Обустављен је рад са корисницима, а сви они који спадају у ризичне групе због придружених болести, старији од 60 година и мајке са малом децом, упућени су на рад од куће. Остали запослени, поштујући радно време од 7.00 до 15.00 часова, обављали су започете и текуће послове у установи. Под тим се подразумевало уређење фонда и контакт са корисницима путем телефона и мејла. Корисници нису имали приступ у зграду, а сва задужења продужена су до завршетка ванредног стања.

Набављена су потребна заштитна средства: маске, рукавице, пластични визири, као и асепсол и алкохол за дезинфекцију.

Убрзо је уследио позив да се библиотекари, као и остали запослени у јавним установама, јаве у Црвени крст, како би се ставили на располагање ради пружања помоћи угроженим категоријама становништва. Свако од пријављених покривао је крај у коме станује те је на позив који стари, немоћни и сви који нису у могућности да излазе упућују Црвеном крсту, одлазио у помоћ. Ујутру се одлазило на посао у 7.00 часова, па се након позива за интервенцију кретало на задату локацију. У међувремену је успостављан контакт са онима који су тражили помоћ и услуге ради најаве доласка и припреме потребних ствари. Услуге су биле различите врсте:

\footnotetext{
3 Чеврнтија је место на десној обали Саве, познато из Првог светског рата. Након победоносне Церске битке, савезници су тражили да српска војска пређе у офанзиву и пребаци се на леву, сремску обалу Саве. Тимочка дивизија 6. септембра прелази реку код Чеврнтије и долази на поље Легет. Непријатељ је успео да потисне Тимочане, наневши им тешке губитке. Из строја је избачено преко 6000 војника, од којих се највећи део утопио у Сави, јер није умео да плива. - Милић Ј. Милићевић, „Старе-

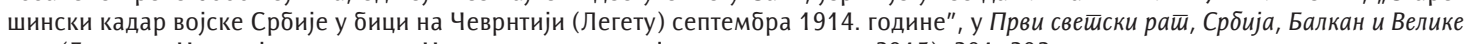
силе (Београд: Историјски институт; Институт за стратегијска истраживања, 2015), 291-293.

${ }^{4}$ „Одлука о проглашењу ванредног стања", Службени іласник РС број 29 (2020), преузето 9. 11. 2021, https://www.pravno-informacioni-sistem.rs/SIGlasnikPortal/eli/rep/sgrs/predsednik/odluka/2020/29/1/reg.

5 „Наредба о проглашењу епидемије заразне болести COVID-19”, Службени іласник PC број 37 (2020), преузето 9.11 .2021 , https://www.paragraf.rs/propisi/naredba-proglasenje-epidemije-zarazne-bolesti-covid-19.html.
} 
набавка разноврсних потрепштина, подизање новца, ношење хране, набавка маски и средстава за дезинфекцију или једноставно мало разговора са усамљеним и уплашеним људима. На одређеним тачкама у граду постављени су велики канистери са дезинфекционим средством те се ту точила течност у мање посуде и носила тамо где је било потребе за тим. Викендом је организована акција дезинфекције зграда и јавног простора, па су волонтери са канистерима на леђима обилазили задате локације.

Сви ангажовани на терену, волонтери града Шапца (ту се рачунају и библиотекари, њих 10), добили су ново задужење у виду поделе заштитних маски. Радило се у пару, уз вођење евиденције.

За то време, у самој библиотеци почело је шивење заштитних маски од материјала који је остајао од ранијих радионица. У први мах, маске су дељене онима који су се јављали да су им потребне, а нису били у могућности да дођу до њих. Када се прочуло за ову акцију, грађани су сами доносили материјале. Продуктивност је порасла, а маске су се делиле и у установама попут Геронтолошког центра. Подела маски у граду прерасла је у акцију која се проширила и на предграђе.

Почетком јуна, када су мере почеле да попуштају, окончана је кампања поделе заштитних маски. По попуштању мера, библиотека је почела да ради на начин прилагођен специфичној ситуацији. ${ }^{6}$ Рад са корисницима одвијао се преко шалтера. На једном прозору / шалтеру остављали су задужене књиге, а на другом су задуживали нове. Резервације књига, ради бржег и ефикаснијег деловања, вршене су и телефоном, мејлом, путем смс порука или апликације Viber. Тако су корисници по доласку могли одмах да преузму своје публикације. Враћене књиге одлагане су у посебну просторију и ту су боравиле 7 дана. Након дезинфекције, враћане су у фонд. Пошто су сви програми отказани, а како читаонице нису радиле и корисници нису могли да уђу у зграду, комуникација са њима се одвијала и путем веб-странице и друштвених мрежа, а одабрани програми су постављани на YouTube канал Библиотеке шабачке.

Пауза је трајала до краја јула, када је спроведена нова акција помоћи суграђанима. Крајем јула и током целог августа припремани су заштитни пакети за грађанство. Окончањем овог посла престало је ангажовање библиотекара те су могли да се врате редовним радним обавезама.

\section{Закључна разматрања}

Две кризне ситуације, свака понаособ, откриле су следеће: нови, ванредни услови живота, рада и свеукупног деловања показале су прилагодљивост и људи и саме установе. У оба случаја извршена је реорганизација послова у библиотеци, сходно броју присутних и ситуацији на терену. Установа је успела да одговори на изазов и да прилагоди свакодневне стручне послове и промотивне активности виртуелном свету и онлајн окружењу.

Запослени су показали спремност да буду активни у волонтерском раду и у поплави и у пандемији и то је разлог што се рад бави управо овим сегментом њиховог деловања. На примеру Библиотеке шабачке, у овом тексту је приказано како су, у условима ванредних ситуација, без разлике да ли су угрожени имовина или животи и здравље људи, библиотекари пружали услуге својој локалној заједници које нису саставни део њиховог професионалног деловања и тиме доказали да су у свим околностима њен неодвојиви део.

\footnotetext{
${ }_{6}$ „Библиотека почела са радом“, Радио телевизија Шабац, 4. 5. 2020, преузето 9. 11. 2021, https://www.youtube.com/ watch?v=-RafCACjVPo.

7 Библиотека шабачка, преузето 10. 9. 2021, https://bibliotekasabac.org.rs; Библиотека шабачка, Facebook, преузето 10. 9. 2021 https://www.facebook.com/biblioteka.sabacka/; Biblioteka šabačka, YouTube, preuzeto 10. 9. 2021, https://www.youtube.com/ user/bibliotekasabacka.
} 


\title{
Литература и извори:
}

1. „Biblioteka počela sa radom“. Radio televizija Šabac, 4. 5. 2020. Preuzeto 9. 11. 2021. https://www. youtube.com/watch?v=-RafCACjVPo.

2. Biblioteka šabačka. Facebook. Preuzeto 10. 9. 2021. https://www.facebook.com/biblioteka.sabacka/.

3. Biblioteka šabačka. Preuzeto 10. 9. 2021. https://bibliotekasabac.org.rs.

4. Biblioteka šabačka. YouTube. Preuzeto 10. 9. 2021. https://www.youtube.com/user/bibliotekasabacka.

5. Bokun Đinić, Sonja, Nadežda Radovanović i Vesna Timotić. Od Čitališta šabačkog do Biblioteke šabačke: 160 godina trajanja. Šabac: Biblioteka šabačka, 2007.

6. Milićević, Milić J. „Starešinski kadar vojske Srbije u bici na Čevrntiji (Legetu) septembra 1914. godine". U Prvi svetski rat, Srbija, Balkan i Velike sile. Beograd: Istorijski institut; Institut za strategijska istraživanja, 2015.

7. „Naredba o proglašenju epidemije zarazne bolesti COVID-19”. Službeni glasnik RS broj 37 (2020). Preuzeto 9. 11. 2021. https://www.paragraf.rs/propisi/naredba-proglasenje-epidemije-zarazne-bolesti-covid-19.html.

8. "Odluka o proglašenju vanrednog stanja". Službeni glasnik RS broj 29 (2020). Preuzeto 9. 11. 2021. https://www.pravno-informacioni-sistem.rs/SIGlasnikPortal/eli/rep/sgrs/predsednik/ odluka/2020/29/1/reg.

\section{Libraries and Red Alert: Experience of the Šabac Library during the Flood and Covid-19 Pandemic}

\author{
Summary \\ Two crisis situations - the flood in 2014 and the Covid-19 pandemic in 2020, caused major changes in the work of the \\ Šabac Library. During those crisis periods, librarians were directly engaged in the field and adapted the work of the \\ institution to the given circumstances. The paper analyzes the similarities and differences in the work of the library \\ during the two mentioned emergencies. In both cases, the library had to change its usual model of working with \\ users, and librarians had to get involved in helping the local community. The difference is that during the flood, the \\ property of our fellow citizens was endangered, while during the pandemic, their lives and health. The Šabac Library \\ has shown the ability to adapt in both situations, so it has managed to retain its users and improve information and \\ educational work with them.
}

Keywords: Šabac Library, state of emergency, flood, COVID-19 pandemic, librarians, library funds, services, social networks, humanitarian work 